\title{
Environmental agreement under the non-interference principle: the case of ASEAN agreement on transboundary haze pollution
}

\author{
Fikri Muhammad ${ }^{1,2}$ (D)
}

Accepted: 3 August 2021 / Published online: 11 August 2021

(c) The Author(s) 2021

\begin{abstract}
It is widely understood that the environmental problem is getting borderless and challenging, requiring concerted efforts of many states and increasing the need for international agreements. However, only for the agreement to exist may not be sufficient- the agreement needs to be credible: obliging the signatories with actions associated with the goal, displaying clear and unambiguous rules, and involving third parties in the dispute settlement. Unfortunately, in the presence of the non-interference principle, the creation of a credible agreement may be implausible as, conceptually, the principle is innately antipodal to hard obligations and third-party involvement in the dispute settlement. This case study seeks to understand how the legalization of the ASEAN Agreement of Transboundary Haze Pollution conformed to the non-interference principle and influenced Indonesia, the main laggard, in dealing with the predicament accordingly. Diverging with the common understanding, the agreement seems to carry strong obligation and precision, as shown in the main agreement and its protocols. However, the apparent downside lies in the lack of delegation dimension, as the current dispute resolution is made through diplomatic efforts that led to fruitless outcomes. This study counters the simplistic view of the association between the non-interference principle and the lack of obligations. Overall, this study points out the importance of the delegation dimension in regionalization and encourages the interventionist approach concerning global environmental protection.
\end{abstract}

Keywords Legalization · Non-interference principle $\cdot$ Hard law $\cdot$ Transboundary haze · ASEAN

Fikri Muhammad

fikri.muhammad@students.uni-freiburg.de; fikri.muhammad21@ui.ac.id

1 Fakultät für Umwelt und Natürliche Ressourcen, Albert-Ludwigs-Universität Freiburg, Tennenbacher Str. 4, 79106 Freiburg im Breisgau, Germany

2 Institute for Economic and Social Research Faculty of Economics and Business, Universitas Indonesia, Jl. Salemba Raya IV, Daerah Khusus Ibukota Jakarta 10430, Indonesia 


\section{Introduction}

The existence of the non-interference principle in the realm of international relations, generally referring to the state's right in dealing with internal and external affairs independently, has been undeniably controversial and received many interests from international relations and political science scholars. Philosophically, the scholarly discourse revolves around its relationship with the notion of liberty and whether it is a fundamental right (Aloupi, 2015; Mariotti \& Veneziani, 2017). Meanwhile, for empirical studies mainly discuss the yin and yang of its implementation. ASEAN is conceivably the central regional institution of interest, given its long-standing history with the principle.

The proponents assert that the principle has facilitated peace and security in the region since its inception, at least in the realm of traditional security (Borchers, 2014; Kivimäki, 2015; Caballero, 1998; Collins, 2007; Stubbs, 2019). Some even regard ASEAN as one of the better models for a regional security regime. Many scholars claimed that the principle is not rigid and static, and the member states have always been intervening with each other on the domestic issue (Bellamy \& Drummond, 2011; Howe \& Park, 2017; Jones, 2007, 2010, 2013; Katanyuu, 2006; Katsumata, 2004; Nguitragool, 2011; Yukawa, 2018). Howe and Park (2017) contended that humanitarian issues are congenial with the 'ASEAN Way' and the default in addressing such agendas, like the transboundary haze and women's peace \& security, is not exclusively due to the principle's constraining nature (Davies, 2016; Zhang \& Savage, 2019). It essentially denotes that, in the execution particularly related to humanitarian issues, the non-interference principle is not incessantly harmful, as it can accommodate strategies to address the issue.

On the other hand, the opponents claimed that the principle has profoundly slowed down the efforts to deal with such issues, as this principle was often leveraged as the excuse for inactions towards the problems (Stubbs, 2019). The most apparent case was during the East Timor crisis, where ASEAN was virtually absent during the pursuance (Dupont, 2000). Another example, Borchers (2014) explained that multilateral defense cooperation's progress remains sluggish, despite recognizing the needs in the ever-increasing non-traditional security challenges, particularly large-scale disasters. Regarding the transboundary haze, Singapore has conceived the limiting nature of the principle, dragging the endeavor to deal with the problem (Ramcharan, 2000). Kuhonta (2006) coined the term 'illiberal peace' as ASEAN's history of peace \& security constrained the effort to engage with the Myanmar junta. Lastly, Capie (2012) concluded that the Responsibility to Protect norm had not been entirely diffused in the region. The opponents intuitively narrate that ASEAN's humanitarian problem might have been less pervasive had the principle is not present.

Concordant with Nguitragool (2011), I argue that one of the non-interference principle's main drawbacks, sometimes regrettably disregarded, is that the principle inhibits the creation of credible agreements. What I refer to as a credible agreement is as such that it exhibits the characteristics of hard law; obliging the signatories in regards to the goal, displaying clear and unambiguous rules, and involving third parties in the dispute settlement. This form enlarges the signatories' commitment credibility and reneging cost (Abbott \& Snidal, 2000; Guzman, 2005; Shaffer \& Pollack, 2010); therefore, it is arguably more effective in binding the signatories in adhering to the obligations. This view is supported by some empirical studies regarding transboundary environmental problems, as harder international environmental agreements showed more desirable 
outcomes (Friedman et al., 2018; Mäder et al., 2010; Skjærseth et al., 2006; von Stein, 2008). However, the non-interference principle hinders the development of hard laws as, conceptually, the principle is innately antipodal to hard obligations and third-party involvement in the dispute settlement.

Serving as another empirical evidence, this essay attempts to analytically assess how the legalization of the ASEAN Agreement of Transboundary Haze Pollution (AATHP) conformed to the non-interference principle and influenced Indonesia, the main laggard, in dealing with the predicament accordingly. I utilized the legalization concept developed by Abbott et al. (2000) to uncover its obligation, precision, and delegation standing and, thus, its position in the hard-soft law continuum. Corresponding with the argument, I hypothesize that the non-interference principle softened its legalization, bestowing Indonesia a leeway to advance its interest that is contradictory with the goal. The study does not intend to assess the effectiveness of AATHP explicitly as such a causal analysis is hard to justify. Instead, it directs to elaborate on recent events that reflect Indonesia's conformity and compliance with the agreement. Such a manner is appropriate since institutionalization and conformity \& compliance are crucial elements of an agreement's effectiveness. This study will provide another piece of argument as to the global environmental protection regimequestions revolving around the aptitude of interventionist versus non-interventionist approach in dealing with the global environmental problem.

Following this part, the concept of hard \& soft law and legalization will be briefly explained. After that, I seek to analyze the structure of AATHP regarding the dimensions, put it in the hard-soft law continuum, and unearth theoretical repercussions to the compliance. Then, I attempt to analyze three recent events connected to the transboundary haze issue attributed to the agreement's legalization. Next, I will discuss the result and, finally, draw an overall, brief conclusion about its implication to global environmental governance.

\section{Hard law, soft law, and legalization}

\subsection{Hard law and soft law}

There have been ongoing debates revolving around hard and soft international agreements. Hard law is one of the principal methods to increase the states' commitment credibility and the cost of reneging due to the consequences for legal violations (Abbott \& Snidal, 2000; Shaffer \& Pollack, 2010). Harder law improves the transaction costs of subsequent interactions given its delegation property. It may also urge states to sign the agreement due to reputational concern and difficulties in shirking (Simmons, 2000; von Stein, 2008). A few studies claimed that some international environmental agreements on the harder side of the continuum, such as Kyoto Protocol, Montreal Protocol on ozone depletion, CITEs, and EU LCP Directive were able to achieve their target (Lawrence \& Wong, 2017; Skjærseth et al., 2006; von Stein, 2008).

On the other hand, hard law entails high sovereignty costs, particularly for the laggards (Abbott \& Snidal, 2000; Shaffer \& Pollack, 2010; Simmons, 2000; von Stein, 2008). This high sovereignty cost would be the primary justification of why some states resort not to take part in an agreement. With this high sovereignty cost, states may also fiercely bargain the law to reduce the commitments (Fischhendler, 2008; Simmons, 2000). Furthermore, hard laws are slightly inflexible, challenging, especially in an environmental issue with its high uncertainty and knotty nature (Shaffer \& Pollack, 2010). 
Soft law, conversely, exists mainly to address the high sovereignty cost imposed by the hard law. Its less legalized structure helps to garner broader participation, particularly by the laggards, in sensitive fields (Simmons, 2000; Skjærseth, 2010; von Stein, 2008). For instance, this form of agreement was opted for the Paris Climate Agreement 2015 (Lawrence \& Wong, 2017; Rajamani, 2016). Dupuy (1990) also argued that soft law could define and promote acceptable behavior standards without necessarily forcing binding obligations. Lastly, it could also be an answer to the inflexibility entailed by the hard law.

Unfortunately, the soft law deems inadequate to incentivize the states to improve behavior. As a result, soft law may not be apt for pressing issues. To illustrate, Lawrence and Wong (2017) argued that, despite having broad participation, the voluntary Nationally Determined Contributions (NDCs) would not fill the $\mathrm{CO}_{2}$ reduction gap between the current condition and what climate science tells. Still, it would be tactless to argue that hard law is incessantly better than soft law or vice versa. The key is that an international agreement's structure has implications for the implementation, and it needs to adjust to the condition.

\subsection{Legalization}

The concept of legalization is pivotal in international agreement analysis in helping to place agreements \& treaties in the hard-soft law continuum. According to Abbott et al. (2000), legalization represents an institution's (legal) characteristics, comprising three dimensions; obligation, precision, and delegation. Obligation refers to how binding the rules are. Specifically, a legally binding agreement scrutinizes the participating members under the general rules, procedures, and international law discourse. Precision revolves on how specific and unambiguous the rules are. Finally, delegation discusses third parties' authority to implement, interpret, and apply the rules, resolve disputes among the states, and create rules.

An agreement or a treaty may possess hard obligations if it uses the term of obligations, such as 'must' and 'shall,' in the obligation rules. Rajamani (2016) argued that 'will' is not strong as it implies promise or expectation; meanwhile, 'should,' 'strive,' or 'encourage' entails recommendation. The obligation should be unconditional, meaning that it does not depend on any event to occur. For it to be legally binding, it should involve traditional legal formalities of signature, allow ratification, implicate 'entry into force,' be registered in the depositary, and state its relationship with pre-existing rules (Abbott et al., 2000).

Abbott et al. (2000) defined a precise rule as a clear and unambiguous rule. They should be coherent and non-contradictory with the other pre-existing rules. A 'rule-like' normative prescription allows ex-ante assessment, while a 'standard-like' prescription requires ex-post assessment. However, Percy (2007) argued that too much precision in law might generate some loopholes in the form of 'expression unius est exclusio alterius,' meaning that 'to express one thing is to exclude the other.' As shown from the anti-mercenary law, the precise definition of mercenary makes the law itself relatively easy to dodge.

Lastly, Abbott et al. (2000) divided delegation into two types: (1) dispute resolution mechanism, where highly legalized treaty assign third-party for decision making over disagreements, and (2) rule-making and implementation, in which third-party is involved in elaborating imprecise legal norms, implementing the rules, and facilitating enforcement. A high delegation dimension is crucial if a law exhibits a low precision and requires ex-post assessment since it prohibits self-serving auto-interpretation and reduces the transaction cost for dispute resolutions. 
In conjunction with the definition, legalization varies significantly for each dimension, suggesting that it is slightly unfitting to strictly partition agreements and treaties into dichotomous classifications: hard and soft law. An agreement or treaty is hard if it exhibits a high degree of obligation, precision, and delegation; meanwhile, agreement or treaty gets softer as one or several dimensions get weakened. Furthermore, one needs to exercise the concept carefully as the view of legalization generated from the concept is limited. In the sense of law, the legalization includes the features \& effects of legitimacy and the congruence of law \& underlying social practice (Finnemore \& Toope, 2001). Unfortunately, these features are not covered in the three dimensions.

Regardless of that, the concept of legalization by Abbott et al. (2000) still offers a solid framework to analyze the structure of an international agreement. The framework provides a reasonable means to put an agreement in the hard-soft law continuum. For that reason, it makes an assessment of the potential effectiveness of an agreement increasingly convincing.

\section{Legalization of AATHP}

Based on the analysis, besides exhibiting characteristics of a legally binding agreement, it is relatively straightforward that the agreement pressures the member states up with adequately substantial obligations in preventing transboundary haze, which in some way may distress the sovereignty. It also provides reasonably precise demarcation of the obligations, further enhanced by enacting protocols to support its implementation. However, one significant shortcoming of this agreement, corresponding to the 'ASEAN way,' is that it has a low to none delegation dimension. It only depends on negotiation and the domestic legal system. Using notation used by Abbott et al. (2000), AATHP seems to be ranging from $\{\mathrm{O}$, $\mathrm{p},-\}$ to $\{\mathrm{O}, \mathrm{P},-\}$, implying moderate law overall, not soft nor hard.

Table 1 provides a summary of AATHP's legalization characteristics. This part tries to provide the arguments to support the claims above and the potential implications for the implementations.

\subsection{Obligation}

AATHP posits hard obligations to the member states. First, it employs a language of obligation 'shall' in the agreement. While it does not utilize "must," a stronger term for obligation, the use of "shall" still indicates an intention of binding obligations and rights (Rajamani, 2016). Article 4 articulates the member states' general obligations as follow:

"In pursuing the objective of this Agreement, the Parties shall: 1. Cooperate in developing and implementing measures to prevent and monitor transboundary haze pollution [...] 2. [...] respond promptly to a request for relevant information or consultations sought by a State or States that are or may be affected [...] 3. Take legislative, administrative, and/or other measures to implement their obligations under this Agreement" (Article 4, AATHP).

Secondly, it displays the characteristics of a legally binding agreement as it; (1) calls for the traditional formalities in an international agreement with the provision of signatures from the member states' representative; (2) is subject to ratification within the domestic legal system which, then, needs to be submitted to the Secretary-General of ASEAN as the 


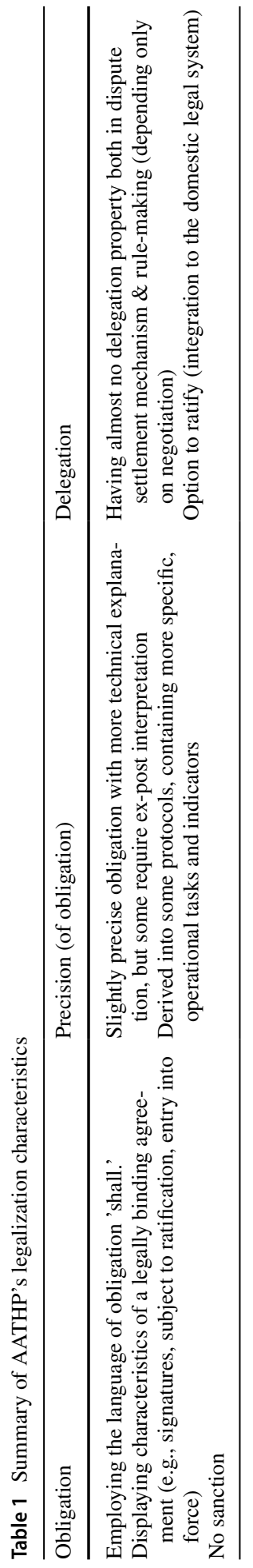


depository, corresponding to Article 28 and 31; (3) includes the terms of "entry into force," as stated in Article 29; (4) states its association with the pre-existing rules within ASEAN with Article 26 and protocols derived from it with Article 21; (5) allows a formal process of an amendment as stated in Article 22. One major downside of the agreement is that it does not introduce any sanction if a breach of the agreement happens.

At first glance, the obligations may look arbitrary and harmless as they sound very normative. However, given ASEAN's uniqueness as a regional intergovernmental association, the obligations entail distinctive implications to the member states. Firstly, burdening the member states in executing a set of measures to prevent transboundary haze defies the ASEAN's central principle of non-interference. This agreement poses a relatively higher sovereignty cost to the member states than the other agreements. With the agreement, they may lose autonomy in decision-making, especially related to natural resource management $\&$ environmental protection, and are exposed to international scrutiny at the regional level. Consequently, the agreement also creates a more considerable contracting cost. This high cost is very apparent with Indonesia's late decision on ratification that took place 12 years after the agreement was signed.

However, this shift can be considered as a vertical movement, since few events have challenged the principle, such as the humanitarian crisis in East Timor (Dupont, 2000) \& transboundary haze itself (Ramcharan, 2000) before the agreement and humanitarian crises in Myanmar over Cyclone Nargis (Bellamy \& Drummond, 2011) \& Rohingya crises (Kaewjullakarn \& Kovudhikulrungsri, 2015) among the recent ones. Specific to transboundary haze, Singapore has recognized the adverse effect of the non-interference principle to solving transboundary haze even since the 1990s (Ramcharan, 2000).

Secondly, it is essential to note that the agreement corners Indonesia as the main laggard concerning the transboundary haze. One issue is that Indonesia has always been regarded as the dominant force, or even the natural leader of the ASEAN (Emmers, 2014; Ramcharan, 2000), and this agreement may somehow hurt the pride that it has. An arbitrary obligation to cooperate or joint emergency response, for example, would look different as it gives an impression of belittling Indonesia's capacity to tackle the problem. Consequently, Indonesia may exhibit non-cooperative behaviors that disregard the AATHP's cooperative spirit. Indonesia's reaction to the joint emergency response will be discussed more in the next part.

Lastly, no sanction may impair its effectiveness as it is among the essential properties to enhance the effectiveness (Heilmann, 2015; Lawrence \& Wong, 2017; Sunchindah, 2015). Lawrence and Wong (2017) said that clear sanctions in the Montreal Protocol, CITES, and WTO agreements are integral in their success. With this condition, any legal remedy may precede nothing if the main laggard does not have the willingness to cooperate.

\subsection{Precision}

Arguably, AATHP encloses a relatively precise demarcation of the obligations. Although the main agreement does not include any numerical criteria, hence requiring ex-post interpretation, general obligations articulated in Article 4 are broken down into several articles, comprehending more technical, specific aspects. For instance, Articles 5-8 discuss how monitoring and information exchange would be instigated. Article 9 obligates member states with several strategies to prevent transboundary haze. Among them are legislative $\&$ authoritative measures for zero burning policy, strengthening local fire management $\&$ firefighting capacity, public education, and awareness-building programs. Articles 12-15 
operationalize internal and external cooperation for joint emergency response. Part 3, consisting of Articles $16 \& 17$, explains technical cooperation and scientific research.

Additionally, the member states develop some protocols and standard operational procedures (SOP), mandated by Article 21, that serve as guidelines with more accountable rules. These protocols enhance the agreement's precision vastly. For example, ASEAN Peatland Management Strategy (APMS) 2006-2020 contains more than 70 operational action plans that provide explicit measures that member states have to carry individually and collectively. The Roadmap on ASEAN Cooperation Towards Transboundary Haze Pollution Control with Means of Implementation 2016-2020, similarly, comprises eight key strategies, broken down into several operational action plans. Furthermore, it also has clear numeric indicators, hence needs no ex-post interpretation to determine if it generally is successful or not.

Nevertheless, there are two more things to consider concerning its precision dimension. Firstly, as Abbott et al. (2000) explained, precision implies that each rule should not contradict the other rules. However, in this case, hard obligations are contradictory to ASEAN's non-interference principle, reducing the agreement's precision to a certain level. In particular, the protocols provide specific tasks that each member state should undertake, denoting more intrusion. Unfortunately, this condition is inevitable for all hard laws, and, eventually, there would always be a trade-off between obligation and precision. Secondly, ex-post interpretation will increase transaction cost through negotiation and dispute resolution (Abbott et al., 2000; Kahler, 2000). While the protocols elaborate on some tasks, the rest remains broad and demands further interpretation. It is apparent with Article 4, Paragraph 2, about information exchange discussed in the next part.

\subsection{Delegation}

One apparent loophole of the AATHP is the lack of third parties' role in the execution, both in the rule-making and dispute resolution mechanisms. There is no specific explanation of external parties' role besides the joint emergency response, technical cooperation, and scientific research. It infers that external institutions do not have parts to engage in any legal proceeding. The rule-making process, related to the interpretation of imprecise norms and the how-to, is entirely carried out by the member states. For instance, as expressed in Article 21-23, amendments and protocols creation would be formulated by the member states.

Furthermore, any conflict that arises over interpretation and application would be resolved internally, as Article 27 states: "Any dispute between Parties as to the interpretation or application of, or compliance with, this Agreement or any protocol thereto, shall be settled amicably by consultation or negotiation." It is, once again, essentially due to the non-interference principle. The only way to improve the delegation dimension would be through ratification as, consequently, it will be internalized within the domestic legal system.

The delegation dimension would be critical when a treaty or an agreement exhibits low precision, as high delegation constraints self-serving auto-interpretation. Low delegation aspects may increase transaction costs for dispute resolution among the conflicting parties, especially when the agreement is incomplete and needs ex-post interpretation (Abbott \& Snidal, 2000; Kahler, 2000). While lack of delegation may reduce the sovereignty cost and contracting cost (Kahler, 2000), it would not arguably put a considerable reduction in this case, since ASEAN has been performing the way of internal dispute settlement with the 
Treaty of Amity and Cooperation since 1976 and the rule of procedure of ASEAN High Council since 2001 (Haacke, 2003). Even without the delegation dimension, the agreement already exhibits high sovereignty cost seen in the very late Indonesia's ratification.

Also, despite improving the delegation dimension, ratification does not necessarily increase the enforcement as states might feel they have ultimate control over the domestic legal system (Abbott \& Snidal, 2000). A dysfunctional litigation system, hence, might not improve the delegation dimension. While not directly connected with the issue, Indonesia is well-known for its corrupted courts (Butt \& Lindsey, 2010). Furthermore, the local community's concern should match other member states' concerns; otherwise, the ratification and domestic litigation system may not advance their interest.

\section{Indonesia's (recent) compliance to AATHP}

As mentioned before, Indonesia has been regarded by the members as the de-facto leader of the ASEAN, granted its vast geographical dimension, large population, strategic position, and natural resource (Emmers, 2014). The gesture of leadership is shown, for example, from its prominent role in the development of the ASEAN Political-Security Community that was primarily conceptualized by its Ministry of Foreign Affairs (Heiduk, 2016). Despite it, Emmers (2014) argued that its leadership is limited to political and security spheres. This study supports the argument in the realm of environmental issues.

This part will discuss three events related to Indonesia's uncooperative behavior in the transboundary haze issue. The first event describes Indonesia's unwillingness to cooperate for joint emergency responses. The second event revolves around information sharing and ex-post rule interpretation. While the last one, related to the effect of ratification, concerns the domestic litigation process.

\subsection{Joint emergency response}

Singapore and Malaysia have always supported Indonesia by offering assistance in dealing with fire and transboundary haze pollution; however, Indonesia does not always respond positively. These uncooperative behaviors were displayed in the latest two big forest fires in 2015 and 2019.

During the 2019 fire, the two countries expressed their concern and willingness to deal with the problem. Yeo Bee Yin, the former Minister of Energy, Science, Technology, Environment, and Climate Change of Malaysia, sent Indonesia a diplomatic note to express her great concern about the recurring haze and offer some assistance to extinguish the fire quickly. Similarly, Singapore had already been undertaking diplomatic efforts to tackle the haze problem as early as April. As the situation worsened, Masagos Zulkifli, Singapore's Minister of the Environment and Water Resources, mentioned that Singapore wrote another diplomatic note in September to inform the details of its firefighting assets at Indonesia's disposal (Zulkifli, 2019). However, Indonesia did not take the offers; instead, this diplomatic effort started rows between Indonesia and Malaysia.

An acting spokesman of Indonesia's National Disaster Mitigation Agency responded to the notes by saying that Indonesia did not need any foreign assistance yet, and the country was capable of dealing with it (The Strait Times, 2019). Furthermore, instead of being helpful, Siti Nurbaya, Indonesia's Minister of Environment and Forestry, objected that the haze covering Malaysia came from its own land and demanded Malaysia to be more 
objective and transparent (The Star, 2019). Yeo then responded to it by asking for Indonesia not to be in denial. She showed 474 and 387 hotspots in Kalimantan and Sumatera with a Facebook post, respectively, while only seven hotspots were detected in Malaysia. She accentuated the post by writing, "Let the data speak for itself. Minister Siti Nurbaya should not be in denial." Indonesia's President Joko Widodo eventually admitted that Indonesia was negligent by letting this issue occurred again (Ihsanuddin, 2019). Despite the confession, Indonesia rejected the offers both from Malaysia and Singapore. The Ministry of Environment and Forestry spokesman reasoned that Indonesia did not want to be degraded by other countries by receiving aids (Wijaya, 2019).

Likewise, this rejection was also outward in the 2015 fire. During the early stage of the fire on the 1st week of September, Vivian Balakhrisnan, the former Minister of Environment and Water Resource of Singapore, extended an assistance package comprising several aircraft for cloud seeding, a team to provide assessment and planning, and high-resolution satellite pictures. However, Siti also refused to take the assistance, believing that Indonesia already had numerous fleets that they were not needed (Jong, 2015). As the fire got overwhelmingly untamed, the government finally decided to be open for foreign assistance. On October 8, President Joko Widodo said that Indonesia sent diplomatic notes to request assistance to Malaysia, Russia, Japan, and Singapore (Gabrillin, 2015). Regarding the refusal before, Pramono Anung, the Cabinet Secretary, explained that Indonesia was open to foreign assistance, but it worried that they would claim the success.

These events suggested that Indonesia does not consider the obligation to cooperate in the AATHP lightly. The rejection was indeed not a violation of the agreement, as Indonesia is allowed to decline the offers. However, even the so-called arbitrary and harmless obligation may bring grave implications to the laggard to the point that it avoided implementing it.

\subsection{Concession maps request}

Following the fires and haze in 2013, Singapore enacted the Transboundary Haze Pollution Act (THPA) 2014 that creates an extra-territorial liability regime and allows the government to prosecute any companies and individuals linked to forest and peatland fire in neighboring countries (Tan, 2018). Had a Singaporean company or individual is guilty of deliberately contributing to the transboundary haze, both directly or indirectly through management or operational affairs \& ownership, the court may put a fine for SGD100,000 per polluted day with a maximum of SGD 2 million. Tan (2018) mentioned that this act is Singapore's response to Indonesia's allegations that some plantations are Singapore-registered companies. However, after more than five years of coming into force, the act is not successful yet in sentencing suspects.

The problems lie with the concession map to identify the liable parties. Tan (2018) explained that the map could come from any organization that can provide it accurately and legally, including the companies themselves. The first thought would go to the government's official maps as they should be the most accurate and official than the other sources. This map would be robust for the court as the companies will face significant challenges to prove otherwise. However, Indonesia has not shared any concession map with Singapore, making the act toothless. Singapore has put many diplomatic efforts to obtain the official map from Indonesia's government that result in vain. Among the first ones was during the 2015 fire that was considered the most catastrophic transboundary haze in Southeast Asia. 
Following the fire, Singapore's government issued a legal notice to seven companies and directors allegedly involved in the incident. These companies are Asia Pulp and Paper and its six suppliers; they are Bumi Andalas Permai, Bumi Mekar Hijau, Sebangun Bumi Andalas Woods Industries, Rimba Hutani Mas, Bumi Sriwijaya Sentosa and Wachyuni Mandira (The Online Citizen, 2017). The last two companies' case was closed already since they were no longer associated with the burned land; however, the remaining companies' case is still active until now due to the non-existent concession map.

Unfortunately, instead of providing the information as requested, in 2016, Siti Nurbaya decided to review its existing and upcoming bilateral cooperation, with a possibility of termination and cancellation, as a form of objection (Hong, 2016). Indonesia's Ministry of Foreign Affairs reinforced it further by filing another protest through its embassy in Singapore. This action was a regression since it is also contradictory to the spirit of cooperation promoted by AATHP. Still, Singapore keeps negotiating to obtain the information, especially since the 2019 fire also seems to involve Singapore-registered companies (Zulkifli, 2019).

Regardless of that, as Sunchindah (2015) stated, this issue is rather complex as it involves territorial integrity and sovereignty. This objection stemmed out due to the public information sharing restrictions based on Indonesia's law. Right after Singapore's request in 2015, a high official from Indonesia's Ministry of Environment and Forestry explained that concession maps are considered classified information by Indonesian law; therefore, they cannot be disclosed publicly (Soeriaatmadja \& Nazeer, 2015). Consequently, sharing the information means a violation of the law. Furthermore, the Director-general also defended no explicit agreement that demands Indonesia to share the concession map. These conditions, therefore, drive Indonesia to keep the information for itself.

Indeed, Article 4, Paragraph 2 of the AATHP does not explicitly articulate what kind of information to be shared. Thus, with this kind of precision, Indonesian government actions cannot be considered as a violation of the agreement. Unfortunately, the AATHP and ASEAN do not acknowledge third-party in the dispute settlement and depend solely on negotiation and consultation. As a result, the result may be unsatisfactory for one of the parties. In this specific case, the outcome does not favor Singapore.

\subsection{Citizen lawsuit}

In July 2015, a group of people attempted to take advantage of the window of opportunity from the 2015 fire by filing a lawsuit against Indonesia's government over the reoccurring fire in Kalimantan Tengah since 1997 (Wahidin, 2019). It was addressed to Indonesia's President, Minister of Environment and Forestry, Head of National Land Agency, Minister of Health, Minister of Home Affairs, Governor of Kalimantan Tengah, and Regional People's Representative Council of Kalimantan Tengah. Among the petitions, the plaintiff required the government to release procedural regulations of Law No. 32/2009 on Environmental Protection and Management, which are vital for forest fire prevention, establish a hospital for lung treatment, provide the treatment freely, and revise forest development planning. In 2017, the district court of Palangkaraya granted the lawsuit, which was then followed by an appeal but was also rejected by the high court of Kalimantan Tengah. However, the effort of the government to cancel the verdict did not stop there.

In May 2018, President Joko Widodo filed a cassation to the supreme court over the verdict (Antara, 2018). The president believed that the government had put considerable endeavor 
in reducing the extent of the forest fire, including through the release of regulations on field monitoring system \& enforcement and establishment of Peatland Restoration Agency (BRG), which he claimed that "[...] it is clear that forest fire has been reduced more than $85 \%$ [...]" (Wijaya, 2018). The national executive director of Walhi, an Indonesian environmental NGO, stated that this action clearly showed that the government failed to understand the essence of this lawsuit, which is nothing else than to improve the enforcement by releasing procedural regulations as demanded (Jawa Pos, 2018). The result was out in mid-2019, where the supreme court declined the cassation filed, strengthening the verdict dropped by the district court of Palangkaraya. Unfortunately, the community could not sit in relief as it turns out that the government is planning to raise a judicial review. Moeldoko, head of the presidential staff office, spoke that the government does not want to look incompetent in solving forest fire issues in front of other countries (Ristianto, 2019).

This action elicited some critiques from many actors. Fadli Zon, the deputy speaker of the People's Representative Council on Politics and Security, criticized the government for not showing commitment to fighting the wildfires' recurring incidents. Zon explained that, besides the judicial review, the government also promoted hashtag \#sawitbersih, meaning "clean palm oil," on social media (Nana, 2019). \#sawitbersih was a hashtag promoted by the Ministry of Communication and Informatics in educating the public that Indonesia's palm oil helps fighting poverty and sequester carbon. Zon claimed it contra factual as palm estate causes deforestation, forest fire, and global warming. On different occasions, the public policy research manager of Walhi stated that the government should have fulfilled all of the points demanded in the lawsuit even without the verdict. He stated that, instead of filing a judicial review, the government should take this event as an opportunity to conduct complete corrective actions on forestry and plantation governance.

Albeit not directly related to AATHP, this event demonstrates that ratification can only solve the lack of delegation property if several conditions are met. First and foremost, a wellperforming, independent court, and litigation process is a necessary aspect. With it, the government can be held accountable for a particular action, including the international agreement violation. However, a functional court only is not sufficient. The government's willingness to conform to the agreement issue still plays a significant part in the implementation. In this case, Indonesia's government declined to put extra effort into dealing with fire and transboundary haze, as it decided to appeal the verdict. It is both the quality and the willingness. Furthermore, the interest of both the local community and the member states should also align. With different interests between the local community in Central Kalimantan and Singapore's government, ratification may not be sufficient to improve delegation property.

Overall, the aforementioned events indicated that Indonesia's government is still hesitant to exert necessary actions to deal with the problem. As such, the current form of AATHP, as well as its protocols, is not adequate to mend Indonesia's behavior, and its ratification seems merely a 'false' signal of commitment.

\section{Conclusion}

This study was primarily raised because the transboundary haze problem remains a recurring issue in the ASEAN even more than a decade after the ASEAN Agreement of Transboundary Haze Pollution came into force. It raises questions about its inaptitude to grapple with the problem. To answer the question, this study investigates how legalized the agreement is, its implications, and how Indonesia responds to it. I utilized the legalization 
concept by Abbott et al. (2000) to assess the structure and examined three events in Indonesia associated with the implementation. While we cannot say that the haze recurrence is caused solely by the agreement, the finding suggests that the current structure of AATHP seems to be inadequate to drive Indonesia in putting indispensable efforts to solve the wildfire within its jurisdiction.

First, given its status as the sole laggard, the obligation to cooperate appears to belittle Indonesia's ability to solve the problem, which results in non-cooperative behavior. The pride it has, given its substantial power in the ASEAN, deters the cooperativeness vision which AATHP aspires to achieve, shown in the joint emergency response. Regardless, it still implies that the obligations create a burden for Indonesia. Second, the imprecise obligation that requires ex-post interpretation created a loophole for the country to avoid the obligation in sharing vital information for the enforcement of the illegal use of fire in land management as requested by Singapore, resulting in a higher negotiation cost. Third, although not directly related to the AATHP, there is evidence that ratification may induce a better delegation dimension, seen by the verdict imposed by the courts to the fire cases in Kalimantan Tengah. However, its effectiveness depends on the government's goodwill and whether the locals' interest corresponds with the other member states' interest.

Taking one step back, I concluded that the main problem of the non-interference principle in regards to environmental agreements revolves around the delegation dimension. I do not see any problem with its obligation and precision dimension as both are relatively strong, especially if we consider all protocols derived from the main agreement. The finding, thus, coincides with the proponents as, in the implementation, the principle seems not as antipodal as it implies. On the other hand, the agreement's main problem would be the lack of formal dispute resolution. As shown in the previous part, the imprecision of obligation related to information sharing may be solved with a formal dispute resolution. Diplomatic efforts seem to be fruitless, as both parties do a self-serving auto-interpretation of the rules where both arguments are justifiable. Furthermore, ratification seems not helpful in improving the delegation dimension, as shown in the citizen lawsuit case. It further reinforces the need for formal dispute resolution at the international level. Therefore, corresponding with opponents, the non-interference principle seems to slow the process of solving transboundary environmental problems. Overall, the study counters the simplistic view on the non-interference principle and credible agreements: it is not about the lack of obligation or precision, instead it is about the lack of delegation.

This study also points out the major flaw of ASEAN as a regional international association. To improve the agreement, reducing the obligations would be out of the question, and developing a more precise obligation may create another loophole. Hence, the most proper way to improve its execution would involve a third-party, independent institution for dispute settlement. In such a condition, the institution can assist in setting any conflict between the member states and, by allowing the rule-making procedure, it facilitates the decision on compensation in case of a breach. This action will create a more legalized agreement that is arguably more effective in the goal accomplishment. However, adding the delegation property in the agreement is not a modest change as it defies the entire notion of its non-interference principle. Authorizing a third-party organization to interfere with its internal affairs means a threat to the member states' sovereignty that ASEAN aspires to achieve with the non-interference principle. More importantly, incorporating third-party dispute resolution may perturb the peace that ASEAN has established since its inception. Consequently, with this current structure, the change might be impossible to achieve, and, thus, ASEAN will always face credibility and reputational issue because it cannot solve this problem. The study denotes the importance of the delegation dimension in regionalization. 
Lastly, it is widely understood that the environmental problem is getting more borderless and among the most pressing global problems. Problems such as deforestation, for example, do not only affect the country of origin, as their impact goes beyond the jurisdiction, especially if it is large in scale. Ultimately, addressing the problem thus requires concerted efforts among the states and international cooperation. Scholars have recognized the importance of the interventionist approach to push the laggards' efforts to protect their environment and the world. This study raises another argument in favor of the interventionist approach concerning global environmental protection, as excuses in accordance with non-interference and sovereignty may be detrimental to global environmental protection through the channel of weak environmental agreements. This is particularly important because recent agreements, such as the Paris Agreement 2015, exhibits low legalization that may inhibit the effectiveness.

Funding Open Access funding enabled and organized by Projekt DEAL. I am reporting that there is no any financial support for this study.

\section{Declarations}

Conflict of interest The author declares that they have no conflict of interest.

Open Access This article is licensed under a Creative Commons Attribution 4.0 International License, which permits use, sharing, adaptation, distribution and reproduction in any medium or format, as long as you give appropriate credit to the original author(s) and the source, provide a link to the Creative Commons licence, and indicate if changes were made. The images or other third party material in this article are included in the article's Creative Commons licence, unless indicated otherwise in a credit line to the material. If material is not included in the article's Creative Commons licence and your intended use is not permitted by statutory regulation or exceeds the permitted use, you will need to obtain permission directly from the copyright holder. To view a copy of this licence, visit http://creativecommons.org/licenses/by/4.0/.

\section{References}

Abbott, K. W., Keohane, R. O., Moravcsik, A., Slaughter, A.-M., \& Snidal, D. (2000). The concept of legalization. International Organization, 54(3), 401-419.

Abbott, K. W., \& Snidal, D. (2000). Hard and soft law in international governance. International Organization, 54(3), 421-456. https://doi.org/10.1007/S10838-006-0091-2

Aloupi, N. (2015). The right to non-intervention and non-interference. Cambridge International Law Journal, 4(3), 566-587. https://doi.org/10.7574/cjicl.04.03.566

Antara. (2018, August 23). Kasasi Jokowi atas gugatan kebakaran hutan sedang proses di MA. Tempo. co. Retrieved from https://nasional.tempo.co/read/1119965/kasasi-jokowi-atas-gugatan-kebak aran-hutan-sedang-proses-di-ma.

Bellamy, A. J., \& Drummond, C. (2011). The responsibility to protect in Southeast Asia: Between noninterference and sovereignty as responsibility. The Pacific Review, 24(2), 179-200. https://doi.org/10. 1080/09512748.2011.560958

Borchers, H. (2014). ASEAN's environmental challenges and non-traditional security cooperation: Towards a regional peacekeeping force? Austrian Journal of South-East Asian Studies, 7(1), 5-20.

Butt, S., \& Lindsey, T. 2010. Judicial mafia: The courts and state illegality in Indonesia. In E. Aspinall \& G. van Klinken (Eds.), The state and illegality in Indonesia (pp. 189-214).

Caballero Anthony, M. (1998). Mechanisms of dispute settlement: The ASEAN experience. Contemporary Southeast Asia, 20(1), 52-53.

Capie, D. (2012). The responsibility to protect norm in Southeast Asia: Framing, resistance and the localization myth. Pacific Review, 25(1), 75-93. https://doi.org/10.1080/09512748.2011.632967 
Collins, A. (2007). Forming a security community: Lessons from ASEAN. International Relations of the Asia-Pacific, 7(2), 203-225. https://doi.org/10.1093/irap/lc1007

Gabrillin, A. (2015, October 8). Pemerintah minta bantuan asing untuk tangani kabut asap. Kompas com. Retrieved in https://nasional.kompas.com/read/2015/10/08/19433821/Pemerintah.Minta.Bantuan. Asing.untuk.Tangani.Kabut.Asap

Davies, M. (2016). Women and development, not gender and politics: Explaining ASEAN's failure to engage with the women, peace and security Agenda. Contemporary Southeast Asia, 38(1), 106-127. https://doi.org/10.1355/cs38-1e

Dupont, A. (2000). ASEAN's response to the East Timor Crisis. Australian Journal of International Affairs, 54(2), 163-170. https://doi.org/10.1080/713613510

Dupuy, P.-M. (1990). soft law and the international law of the environment. Michigan Journal of International Law, 12(2), 420-435.

Emmers, R. (2014). Indonesia's role in ASEAN: A case of incomplete and sectorial leadership. Pacific Review, 27(4), 543-562. https://doi.org/10.1080/09512748.2014.924230

Finnemore, M., \& Toope, S. J. (2001). Alternatives to 'legalization': Richer views of law and politics. International Law and International Relations, 55(3), 743-758. https://doi.org/10.1017/CBO9780511 808760.012

Fischhendler, I. (2008). Ambiguity in transboundary environmental dispute resolution: The Israeli-Jordanian water agreement*. Journal of Peace Research, 45(1), 91-109. https://doi.org/10.1177/00223 43307084925

Friedman, K., Gabriel, S., Abe, O., Adnan Nuruddin, A., Ali, A., Bidin Raja Hassan, R., Cadrin, S. X., et al. (2018). Examining the impact of CITES listing of sharks and rays in Southeast Asian fisheries. Fish and Fisheries, 19(4), 662-76. https://doi.org/10.1111/faf.12281

Guzman, A. T. (2005). The design of international agreements. European Journal of International Law, 16(4), 579-612. https://doi.org/10.1093/ejil/chi134

Haacke, J. (2003). ASEAN's diplomatic and security culture : A constructivist assessment. International Relations of the Asia-Pacific, 3, 57-87.

Heiduk, F. 2016. Indonesia in ASEAN. Regional Leadership between Ambition and Ambiguity. SWP Research Paper. https://nbn-resolving.org/urn:nbn:de:0168-ssoar-46859-8.

Heilmann, D. (2015). After Indonesia's ratification: The ASEAN agreement on transboundary haze pollution and its effectiveness as a regional environmental governance tool. Journal of Current Southeast Asian Affairs, 34(3), 95-121.

Hong, L. (2016, May 17). Indonesia does a U-turn on haze collaboration with Singapore. Eco Business. Retrieved from https://www.eco-business.com/news/indonesia-does-a-u-turn-on-haze-collaborationwith-singapore/.

Howe, B., \& Park, M. J. (2017). The evolution of the 'ASEAN Way': Embracing human security perspectives. Asia-Pacific Social Science Review, 16(3), 1-15.

Ihsanuddin. (2019, September 16). Jokowi: Kita lalai soal kebakaran hutan dan kabut asap. Kompas com. Retrieved from https://nasional.kompas.com/read/2019/09/16/20401321/jokowi-kita-lalai-soal-kebak aran-hutan-dan-kabut-asap

Jawa Pos. (2018, August 26). Menanti ketegasan pemerintah mengatasi kasus kebakaran hutan dan lahan. Jawa Pos com. Retrieved from https://www.jawapos.com/nasional/hukum-kriminal/26/08/2018/menan ti-ketegasan-pemerintah-mengatasi-kasus-kebakaran-hutan-dan-lahan/.

Jones, L. (2007). ASEAN intervention in Cambodia: From cold war to conditionality. Pacific Review, 20(4), 523-550. https://doi.org/10.1080/09512740701672001

Jones, L. (2010). ASEAN's unchanged melody? The theory and practice of 'non-interference' in Southeast Asia. The Pacific Review, 23(4), 479-502. https://doi.org/10.1080/09512748.2010.495996

Jones, L. (2013). Sovereignty, intervention, and social order in revolutionary times. Review of International Studies, 39(5), 1149-1167. https://doi.org/10.1017/S0260210513000259

Jong, H. N. (2015, September 12). RI refuses Singapore's help in forest fires. The Jakarta Post. Retrieved from https://www.thejakartapost.com/news/2015/09/12/ri-refuses-singapore-s-help-forest-fires.html

Kaewjullakarn, S., \& Kovudhikulrungsri, L. (2015). What legal measures should ASEAN apply to help the Rohingya? South East Asia Journal of Contemporary Business, Economics and Law, 6(4), 27-38.

Kahler, M. (2000). Conclusion: The causes and consequences of legalization. International Organization, $54(3), 661-83$.

Katanyuu, R. (2006). Beyond non-interference in ASEAN: The association's role in Myanmar's national reconciliation and democratization. Asian Survey, 46(6), 825-845.

Katsumata, H. (2004). Why is Asean diplomacy changing? From 'non-interference' to 'open and frank discussion.' Asian Survey, 44(2), 237-254. 
Kivimäki, T. (2015). How does the norm on non-interference affect peace in East Asia? Asian Survey, 55(6), 1146-1169.

Kuhonta, E. M. (2006). Walking a tightrope: Democracy versus sovereignty in ASEAN's illiberal peace. The Pacific Review, 19(3), 337-358. https://doi.org/10.1080/09512740600875119

Lawrence, P., \& Wong, D. (2017). Soft law in the Paris climate agreement: Strength or weakness? Review of European, Comparative and International Environmental Law, 26(3), 276-286. https://doi.org/10. $1111 /$ reel.12210

Mäder, J. A., Staehelin, J., Peter, T., Brunner, D., Rieder, H. E., \& Stahel, W. A. (2010). Evidence for the effectiveness of the Montreal Protocol to protect the ozone layer. Atmospheric Chemistry and Physics, 10(24), 12161-12171. https://doi.org/10.5194/acp-10-12161-2010

Mariotti, M., \& Veneziani, R. (2017). The liberal ethics of non-interference. British Journal of Political Science, 50(2), 567-584. https://doi.org/10.1017/S0007123417000576

Nana, D. (2019, September 18). Hutan selalu terbakar, Fadli Zon: Negara kok kalah melulu oleh mafia. Malang Times com. Retrieved from https:/www.malangtimes.com/baca/44114/20190918/103900/ hutan-selalu-terbakar-fadli-zon-negara-kok-kalah-melulu-oleh-mafia.

Nguitragool, P. (2011). Negotiating the haze treaty: Rationality and institutions in the negotiations for the Asean agreement on transboundary haze pollution (2002). Asian Survey, 51(2), 356-378. https://doi. org/10.1525/AS.2011.51.2.356

Percy, S. V. (2007). Mercenaries: Strong norm weak law. International Organization. https://doi.org/10. 1017/S0020818307070130

Rajamani, L. (2016). The 2015 Paris agreement: Interplay between hard, soft and non-obligations. Journal of Environmental Law, 28(2), 337-358. https://doi.org/10.1093/jel/eqw015

Ramcharan, R. (2000). ASEAN and non-interference: A principle maintained. Contemporary Southeast Asia, 22(1), 60-88.

Ristianto, C. (2019, July 22). Pemerintah ajukan PK soal kebakaran hutan, ini penjelasan Moeldoko. Kompas com. Retrieved from https://nasional.kompas.com/read/2019/07/22/16150841/pemerintah-ajukanpk-soal-kebakaran-hutan-ini-penjelasan-moeldoko.

Shaffer, G. C., \& Pollack, M. A. (2010). Hard vs. Soft law: Alternatives, complements, and antagonists in international governance. Minnesota Law Review, 94(3), 706-799.

Simmons, B. A. (2000). International law and state behavior: Commitment and compliance in international monetary affairs. American Political Science Review, 94(4), 819-835. https://doi.org/10.2307/2586210

Skjærseth, J. B. (2010). Exploring the consequences of soft law and hard law: Implementing international nutrient commitments in norwegian agriculture. International Environmental Agreements: Politics, Law and Economics, 10(1), 1-14. https://doi.org/10.1007/s10784-009-9105-y

Skjærseth, J. B., Stokke, O. S., \& Wettestad, J. (2006). Soft law, hard law, and effective implementation of international environmental norms. Global Environmental Politics, 6(3), 104-120. https://doi.org/10. 1162/glep.2006.6.3.104

Soeriaatmadja, W., \& Nazeer, Z. (2015, August 26). Jakarta law forbids disclosing info on plantation concessions. The Strait Times. Retrieved from https://www.straitstimes.com/asia/se-asia/jakarta-law-forbi ds-disclosing-info-on-plantation-concessions.

Stubbs, R. (2019). ASEAN sceptics versus ASEAN proponents: Evaluating regional institutions. The Pacific Review, 32(6), 923-950. https://doi.org/10.1080/09512748.2019.1611627

Sunchindah, A. 2015. Transboundary haze pollution problem in Southeast Asia: Reframing ASEAN's Response. ERIA Discussion Paper Series ERIA-DP-2015-82. http://www.eria.org/ERIA-DP-2015-59. pdf.

Tan, A. K. (2018). Singapore's new transboundary haze pollution act: Can it really work to prevent smoke pollution from Indonesia? In E. Quah \& T. S. Tan (Eds.), Pollution across borders: Transboundary fire, smoke and haze in Southeast Asia (pp. 265-291). World Scientific Publishing Company.

The Online Citizen. (2017, November 9). Is the Transboundary Haze Pollution Act, a toothless act?. The Online Citizen. Retrieved from https://www.theonlinecitizen.com/2017/11/09/is-the-transboundaryhaze-pollution-act-a-toothless-act/.

The Strait Times. (2019, September 10). To ease haze, Malaysia ready to give Indonesia a helping hand to put out forest fires. The Strait Times. Retrieved from https://www.straitstimes.com/asia/se-asia/to-easehaze-malaysia-ready-to-give-indonesia-a-helpinghand-to-put-out-forest-fires

The Star. (2019, September 11). Yeo on Indonesia's denial of haze: The facts speak for itself. The Star. Retrieved from https://www.thestar.com.my/news/nation/2019/09/11/yeo-on-indonesia0 39s-denial-of-haze-the-facts-speak-for-itself

von Stein, J. (2008). The international law and politics of climate change: Ratification of the United Nations framework convention and the Kyoto Protocol. Journal of Conflict Resolution, 52(2), 243-268. https:// doi.org/10.1177/0022002707313692 
Wahidin, K. P. (2019, October 2). Putusan MA dan pemerintah yang abai atasi karhutla. Alinea id. Retrieved from https://www.alinea.id/nasional/putusan-ma-dan-pemerintah-yang-abai-atasi-karhutla-b1Xoc 9nOM.

Wijaya, M. A. (2018, August 24). Kalah banding kasus karhutla Kalteng, Jokowi ajukan kasasi ke MA. Tirto id. Retrieved from https://tirto.id/kalah-banding-kasus-karhutla-kalte ng-jokowi-ajukan-kasasi-ke-ma-cUAm.

Wijaya, C. (2019, September 21). Kebakaran hutan: Ditawari Malaysia dan Singapura bantuan, Indonesia sebut nanti 'dilecehkan, ah gitu aja minta bantuan'. BBC News Indonesia. Retrieved from https://www. bbc.com/indonesia/indonesia-49765217

Yukawa, T. (2018). The ASEAN way as a symbol: An analysis of discourses on the ASEAN norms. Pacific Review, 31(3), 298-314. https://doi.org/10.1080/09512748.2017.1371211

Zhang, J. J., \& Savage, V. R. (2019). Southeast Asia's transboundary haze pollution: Unravelling the inconvenient truth. Asia Pacific Viewpoint, 60(3), 355-369. https://doi.org/10.1111/apv.12245

Zulfikli, M. (2019, October 7). Written reply by Masagos Zulkifli, Minister for the Environment and Water Resources, to Parliamentary Question on Transboundary Haze on 7 October 2019. Retrieved from https://www.mewr.gov.sg/news/written-reply-by-masagos-zulkifli--minister-for-the-environment-andwater-resources--to-parliamentary-question-on-transboundary-haze-on-7-october-2019.

Publisher's Note Springer Nature remains neutral with regard to jurisdictional claims in published maps and institutional affiliations. 